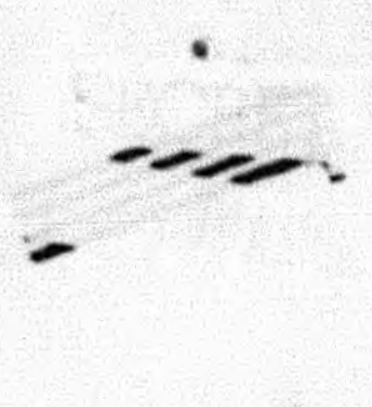

Thls docusent contsins 37 pages

Th1s 18 copy 8 of 37 coplos

Documont tio. (C-0.380.5) Serles A

$$
\text { AECD- } 4102
$$

CHTVRO ENOTIESR WOHES

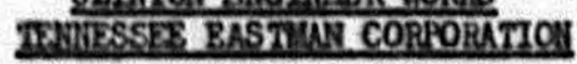

Contract Ilo, $11-7401-0$ a $_{6}-23$

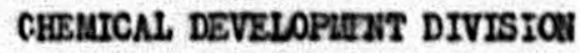

Dr. C. E, Lareon - D1rector

Photostat Price S

7

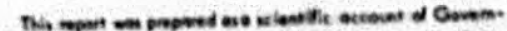

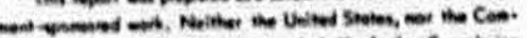

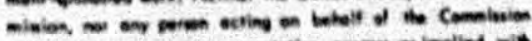

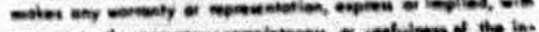

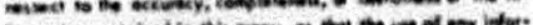

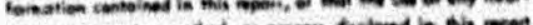

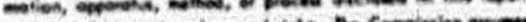

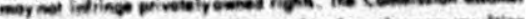

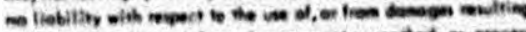

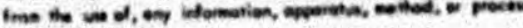
sireloued in this repos.

Department of Commerce

Washington 25, D. C.

\title{
THE COPHECIPITATHON OS
}

THORTOU AND URANTUL PEIOXXIDES

Roy Oreinger

R. F. Floodard

G. B. Larson

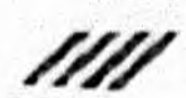

Oak Radge, Tennessoe

Liay 20, 2946

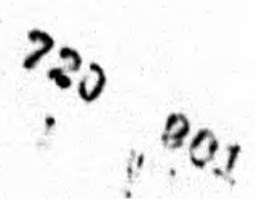




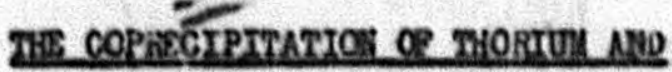

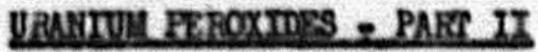

covesins

Pages

Abstract...............................................

I Introduotion. $3-4$

II Dlecuesion of qualltatit to Asposts of Proposod Procese........... $4-5$

III Faotors Affooting Succeseful Copreolpitation

IV Qunntitative Dato Eavoloping Coprecipitation of $\mathrm{m}_{2} \mathrm{O}_{7}-\mathrm{TO}_{4}$

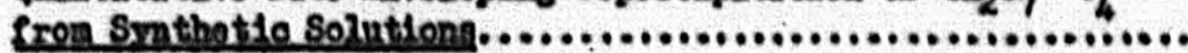

A. Pllot Plant Data......................................

B. Vee of Pecyalod Thor Ium............................ 17-28

$\nabla$ Guantitativo Data Enveloping Coprecipitation of $\mathrm{Th}_{2} \mathrm{O}_{4} \mathrm{OO}_{4}$

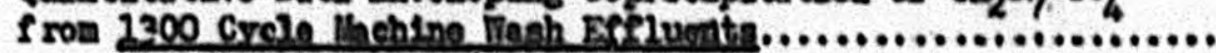

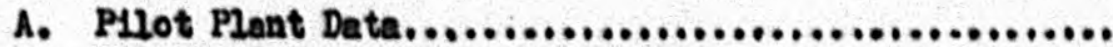

B. Effeot of Tomporature on Reeotion....................

VI Tontative Bocoumondod Plant Oporating Proceduro................

A. Fluoreboones Anelgris................................

B. Bulk Uraniu Analye1s................................

C. Analyols for Inoreasing Thorlun Concontrationa........

D. Ho Dotornination..................................

E. Aipha Counting Experimonts.

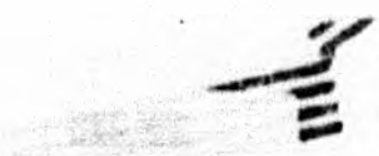




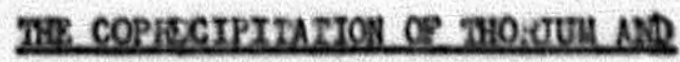

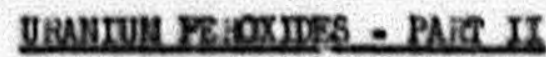

* PIDOr PUNR STaCE

\section{ABSTRACS}

1. Exporiments covoring the coproelpitation of Thorluta and Uranlua perox1des are doecribod on aynthotic and actual 2300 ogelo machine waeh ofeluants.

2. The more Important factore offecting the ctucoessful reaction are d1scuseed.

3. Date are presented on the recovory of the InItial thoriun and 1ts roube a0 a procipitant in mumorous suno, both in ayathot10 and 2300 machino vash offluonts.

4. A tentativo procedure for tho eoprecipltation of $\mathrm{Th}_{2} \mathrm{O}_{7} \mathrm{OO}_{4}$ 1s outlined.

5. It has boen ohom in practically overy case that tho coprocipitation process will recuce Bota machine wah offluonts to 2088 then 2 m uranium por gallon.

6. Alnost no uranlun is lost in the proposed cyclo and tho procipitant can be succesefully recoverod and reusod.

7. Tho reaction becomos more quantitativo with increasing pll and $\mathrm{t} t$. Th/wt. 0 rat10.

8. With the ablilty to accesefuldy recovor uranlun concentrations as high as $200 \mathrm{gg} / \mathrm{L}$ - 18 a emall quant1ty of ureniun is prosent as collo1dal $\mathrm{VO}_{4}$ - there are indications that onrichod naterial, other than from machine wash offluente, can bo troatod aloo.

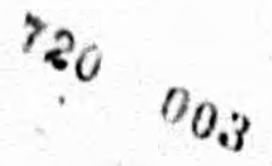


I Introsuation

Aboently this laberatory doveloped a noe proeeest, coneerned primarlly with the rowoval of uranina fros nachlne wash effluonts resulting from the Bota Cold Peroxdde troatment, the rundanantale of whleh are beaod opecifically on tho theory of coprocipltation.

At the tiso of tho InItinl inveatigation, radioaotive tracer work wae a major problea of this group and, roalleing the elfmiricance of carrior nothods, It was suggestod that the use of anothor eloment, forning an inooluble poroxdide in an acid solution, might roact in olmiliar feahion to tho regular poroxido proelpitation and quantitativoly coprocipltato with it any urentum in solution.

Since thoriun is the only othar coman olemont to rulfill the above requiromonts, it was docided to inveotigate ito behavior in pure volutions. Thorlum poroxido formation, reeombling alumiman hydroxido, was woro ovldont with ancreasing thoriun concontrations, whilo diluto thorlun oolutions precipitated more readily with the presence of Increasing anounts of oloctrolytar.

Addition of mall amounts of uranium $(10 \mathrm{me} / \mathrm{h}$ ) to tho thorlus oystem resulthd in the formation of a bright yellow-orange eolld after $\mathrm{B}_{2} \mathrm{O}_{2}$ troptmont, whlch appoered of waxy toxturo upon continued drewing of alr through 1 t.

Analyeis of this procipitate Indicated the presence of the greatost percentage of urenium, whilo it was practically uncietoctablo in the flitrate. With the devolopeent of an offective fluorescence mothod of anslys1s for dotoction of microgram quantitios of uranius in the thorium offiuents, it beame foasible to vary tochnlques and conditions of this coprocipl-

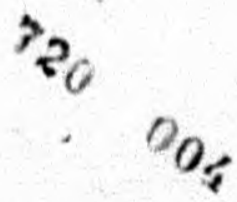


tation process aore cosplotely. Progress froa those varlations has been ouch that at present, num rous ouccessful synthot1e rume have been undortakon at the Purdue Onivore1ty Bota PLot Pant ${ }^{2}$ which esulates exact Bota plent conditions, and cosplote data not only on these suns, but 51 others In our laboratory, of a five gallon oapacity, utllising 1300 cyele matorlal, have been tabulated.

The eajor portion of materlal covered by this roport includes work ecomplishod on a laboratory pllot plant scale. With the ald of this plant, It has buen posaiblo to develop the basic theory of coprecipitation to tho point whore a quantitative removil of uraniun from the machine wash offluonts is now a roality.

\section{Dincuealon of Oonditative Anpects of Broposed Procese}

Parallel vith the developmont of an optinum conditloned procipltation procees, hes been tho devolopment of a mothod for the oeparation of uranium from the mase of thorlua. Thlo constitutes a oinple convoraion of the $\mathrm{Th}_{2} \mathrm{O}-\mathrm{UO}_{4}$, when treated with oxallo acid, to the inooluble $\mathrm{ma}\left(\mathrm{C}_{2} \mathrm{O}_{4}\right)_{2}$ and solublo $\mathrm{VO}_{2} \mathrm{C}_{2} \mathrm{O}_{4}$. The soparation at prosent has attalnod as high as $\% \%$ off101oney and nith considerably nore work contemplated on this phase it is highly probable that aparation approaching quantitativeness w1ll bo achloved. Howover, this apparent $4 \%$ Lose of uraniun in the $\mathrm{Th}\left(\mathrm{C}_{2} \mathrm{O}_{4}\right)_{2}$ calco should bo of no great concern efter tho proposod "preolpitation-recovery cyclen is understood. 


\section{re coletinine chlorination}

Bulk of<smiles>C1C[GeH2][GeH]1</smiles>

3

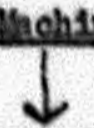

2 Cold Areorde Brectintatioa

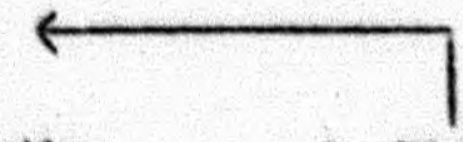

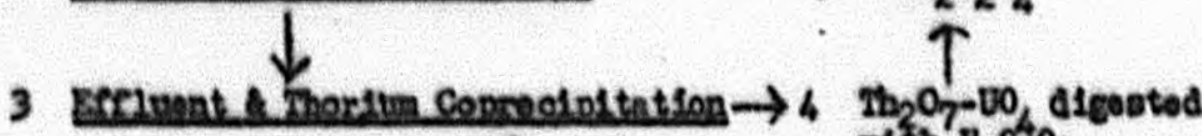

$5 \mathrm{VO}_{2} \mathrm{C}_{2} \mathrm{O}_{4}$

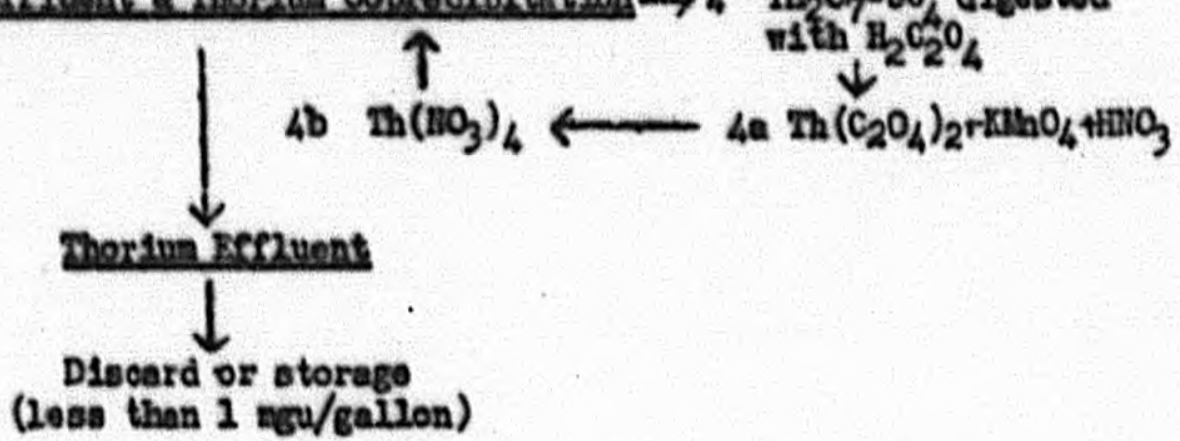

Stops 1 through 5 constituto tho primary cycle of the process whilo $4 \mathrm{a}$ and $4 \mathrm{~b}$, a recevery of the procipdtant, oan bo rogarded ab a ondary oyclo.

In a more dotalled faohlon, lot us consider tho above procens.

Actually no natorial is unaccountod for or wasted in tho wolo. The $\mathrm{Th}_{2} \mathrm{O}_{7}-\mathrm{OO}_{4}$ prealpltoto, rosulting from troatment of the wachine wash ofPluent with a $20 \%$ aquoous $\mathrm{Th}\left(\mathrm{HO}_{3}\right)_{4}$ solution, is digestod with oxallo acid, and the insoluble $\mathrm{Th}\left(\mathrm{C}_{2} \mathrm{O}_{4}\right)_{2}$ is filtored and nashod froe frot $\mathrm{VO}_{2} \mathrm{C}_{2} \mathrm{O}_{4}$. It 18 plennod to return the uraniun oxaleto solution containing approximately $96 \%$ of the $U$ from tho cold poroxdde machino waeh offluont directly to the original machino wash solution. Current investigations eeom to indicato that the oxalato to be roturned as $\mathrm{VO}_{2} \mathrm{C}_{2} \mathrm{O}_{4}$, is of insienificant concentration to offect the cold poroxide procipltation?.

The inctial thorium, nori as $\mathrm{Th}\left(\mathrm{C}_{2} \mathrm{O}_{4}\right)_{2}$, and containing approxinately 45 U unromoved to the oxalato oxtraction ean bo troatod with an ac1d $\mathrm{KMnO}_{4}$ solution, to deconpose the oxnlato and be reused in the original thorium coprocipitation. Thus exy uranium ocoluded with the oxcala to calce lo oventu-

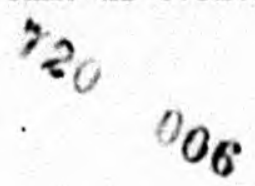


ally returnod, to tho machline naeh oftor ropeated reuse in the prinary and eocondary eycles.

Tho offlusent from the thorlun poroxide, containing lose than 1 me/gal. of uraniun, oan bo diecardod or selvaged.

III Faotore Effeoting Succossful Coprecipitation of $\mathrm{m}_{2} \mathrm{O}_{7}-\mathrm{UO}_{4}$

Considorable prolleninary work Involving saill ocolo puto and eynthotic eystome produced valuable data coscerning tho offeot of other notal 10no, pH control, minimun vtTh/rito ratio, $\mathrm{H}_{2} \mathrm{O}_{2}$ concentration, 11mits of $V$ concontration, timo of aging and rato of contrifugation, on the coproolpitation of $\mathrm{Th}_{2} \mathrm{O}_{7}-\mathrm{NO}_{4}$.

\section{A. Exfent of $\mathrm{pH}$}

Effiolent Uranium renoval beconos more perceptiblo v1th IncreasIng pll over a renge of 1.0 to 2.0 , and although control of the $\mathrm{pH}$ is not critioal ( \pm 0.15$)$ at 2.0 , Incompleto proolpltation and an unfilterablo produot read1ly reoults at a rango loss than 1.8. Procipdtation abovo the range of 2.3, as in any cold peroxdde treatment, usually rearlits in the hydrolyeis of Iron, considorable calco contamination, and subsequent poroxide decomposition.

\section{B. Bresence of Other Matal Ions}

Othor motel 10ns preeent in solution, when in the range of Bota process machine wash offluonte, soomed to have very 11 ttle effoct on the proolpitation: A comparison of the centrifuged cakes and those filtered through Pine sintered glass, showod a sore compact and oloaner product in the formor osse. It was evident only with increasing concentrations of motal 1one ( $.3 \% \mathrm{Fo}$ and $.3 \% \mathrm{Cu}$ ) that urenlum solubllits increased algnif1cantly.

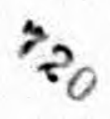


Incomplote data on oako contanination Indicates that undor optimm conditions, contanination by other metal loas lo nogligible. Hegardloss, th1s should bo of no great conoern, for the prochuct is oventually returned to the original machine wash solution and reprocipltated with tho bulk of uraniug es $\mathrm{TO}_{4} \cdot 2 \mathrm{H}_{2} \mathrm{O}$.

\section{Et.Th/it.d inatise}

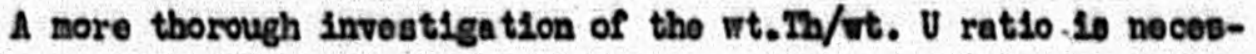
sary before a definito conolusion can bo drawn concorning 1ts optimun rango. At present a Th/irt, $\mathrm{V}$ of 20 to 30 has produced excellent results and tho offlelency seems to increase with inereasing ratios. Docreasing this rat1o tends to delay preclpitation and one run, R-18, after aging for ono hour showed a marked inerease in uranium solubillity.

\section{TABIE I}

EDEECT OF it. Th/Ht, U VARUATIONS

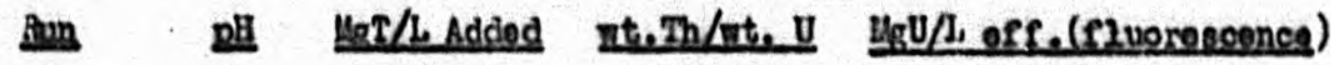

$\begin{array}{lllll}R-15 & 1.5 & 50 & 10 & 9.2 \\ R-13 & 1.5 & 50 & 20 & 7.5 \\ R-18 & 2.0 & 300 & 3.33 & 80 \\ R-17 & 2.0 & 100 & 10 & 1.0 \\ R_{R-12} & 2.0 & 51 & 20 & 0.26 \\ 0-1 & 2.0 & 30 & 33 & 0.09\end{array}$

Conditions: 1 11ter solution precipitatod; -plie2.0, tomp. $44^{\circ} \mathrm{C}$, 30 gins. $\mathrm{NH}_{2} \mathrm{NO}_{3} ;\left(\mathrm{H}_{2} \mathrm{O}_{2}\right)=.5 \mathrm{~N}-\frac{1}{2}-1 \mathrm{hr}$. aging beforo cantrifugation.

Reaults of the preceding pure Th-U solutions indicato very strongly that the coprecipitation bocomos moro quantitative with increasing pH and wt.Th/wt. O ratio.

*.04\% Fo addod
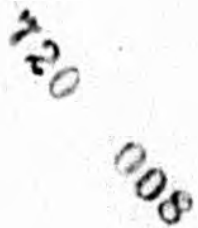
Further Inveet1gation is planned ahortly on the effect produced by varying the $\mathrm{Th} / \mathrm{wt}$. 0 rat10 w1th varying $\mathrm{pll} \mathrm{t}_{\mathrm{o}}$.

\section{D. $\mathrm{H}_{2} \mathrm{O}_{2}$ Concontration}

Numerous sums coen to oubstantisto ovidence that significantly dooreasing $\mathrm{H}_{2} \mathrm{O}_{2}$ concentration reterde tho formation of thorium poroxddo. The optiman $\mathrm{H}_{2} \mathrm{O}_{2}$ concontration appiazed to bo approximatols .5 U and docreaco in uranium bolubility remained negilgtble with increase of $\mathrm{H}_{k} \mathrm{O}_{2}$ above this range.

\section{TABIE II}

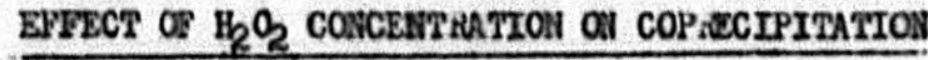

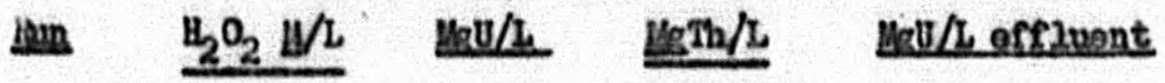

$\begin{array}{lrlll}P-17 & .1 & 30 & 1000 & 1.6 \\ P-16 & .2 & 30 & 1000 & 0.3 \\ P-20 & .5 & 30 & 1000 & 0.2 \\ P-30 & 1.0 & 30 & 1000 & 0.2\end{array}$

Condittiongt ptre2.0, Tom. $=\angle \mathrm{OC}^{3}$ gynthot1e machino wash used con-

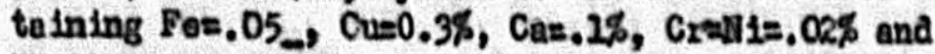
$\mathrm{NH}_{4} \mathrm{Cl}=\mathrm{MH}_{4} \mathrm{NO}_{3}=1.7 \%$. Aged 1 hour and centrifuged.

\section{E. Linite of Uranium Coneentration}

It was proviously roported that 1 gran of $\mathrm{Th} / 1 \mathrm{It}$ tor was Incapablo of coprecipl tating $100 \mathrm{mg} \mathrm{V} / \mathrm{L}$ sucesafully. Since $100 \mathrm{ng} / \mathrm{L}$ is inconsiotont With normal Bote machino wesh offluante, it was not considered of a sorlous nature. Novertheloss, it seomed to indicato that increasing U concentra tion was a critios factor in offlolont uranium ronoval.

Horo recent rork (Tablo JIII) involving actual onriched Beta wachine waoh offluents seoned to discount this theorg, for rune vith 
ef Leonts contalning $100-200 \mathrm{mg} \mathrm{V} / \mathrm{i}$ and $2 \mathrm{gr} \mathrm{m} / \mathrm{h}$ were recucod upon coprecipltation to more nogligiblo quantities than sfrivente containing epproxdrately $10 \mathrm{mg}$ W/L.

Coser Investigation of actual plent eff2uonts rovealed that part of the urantua actunLly exclsted as oollo1dal $\mathrm{VO}_{4} \cdot 2 \mathrm{~h}_{2} \mathrm{O}$. Tho poatprec1p1tated $\mathrm{VO}_{4}$ seoned to aot as a eoed for the proelpitation, ond ras roadily oceludod with tho formation of $\mathrm{th}_{2} \mathrm{O}_{7}$, insuring a more comploto $U$ romoval. It can presontly bo statod that a concontration of approximatos. $200 \mathrm{mg} \mathrm{V} / \mathrm{L}$ cen bo efficlently renoved by tho coproespitation procese if a

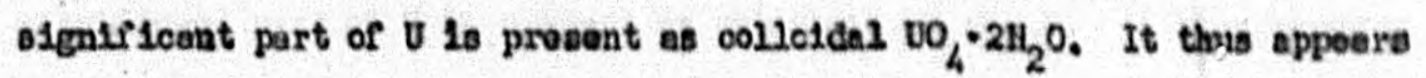
very poesible that additional materind with smell onounts of $V$ destined for oventual zecovery can be blendod Into nachine naeh offluents and euceeseful17 treated by tho thorium coprecipt tation procese.

Efficionog of the coprecipitation appeare to decroase with 0 concentration loes than $5 \mathrm{mg} / \mathrm{h}$. This condition nay not be entirely valid, for the for runs observed produced conflioting results duo to incomploto contrifugation, Conalderably more Invostigation 1s conteraplated on this phase shortly. 


\section{TABIE III}

\section{EFFECT OF U CONCEHTRATIOA ON THORTOR COPRECIPITATIOA}

Iiv

$\begin{array}{rl}P-114 & 100 \\ 39 & 208.8 \\ 42 & 208.8\end{array}$

"B. 8200

*B-18 $\quad 120$

*B-34 $\quad 157$

"B-27

"B-39

$x-4$

6.9

10.0

0.5

2.0 y/math exe.

23

3.6

0.80

U. Bresent as

$\mathrm{VO}_{2}\left(\mathrm{BO}_{3}\right)_{2}-$ addod with Thorium

$\mathrm{UO}_{2}\left(\mathrm{NO}_{3}\right)_{2}$ - " before i

$3 / 4 \mathrm{vO}_{2}\left(\mathrm{HO}_{3}\right)_{2} \quad 1 / 4 \mathrm{TO}_{4}$ ADDED BEFOKL

$\begin{array}{llll}00 & 0.03 & \mathrm{VO}_{2}\left(\mathrm{BO}_{3}\right)_{2} & \mathrm{OO}_{4} \\ 20 & 0.07 & " & " \\ 57 & 0.08 & n & "\end{array}$

$0.80 \quad "$

0.03

,

0.2 "

0.06

n

Conditiones Th $=2 \mathrm{Ex} / \mathrm{L}_{\mathrm{i}} \mathrm{pH}=2.0 ;$ Tomp. $=4.0 \mathrm{O}^{\mathrm{B}} \mathrm{B} \mathrm{O}_{2}=.5 \mathrm{H}$; aged 15 minuteis to 1 hour bafore oentriliugation. Synthotic solution used $-\mathrm{Fo}_{0}=.05 \% \mathrm{Cu}=.5 \%$;

* 1300 Uranium usea $\mathrm{Ca}=.1 \delta_{;} \mathrm{Cr}=\mathrm{N1}=.02 \kappa_{3} \quad \mathrm{mH}_{4} \mathrm{Cl}=\mathrm{NH}_{4} \mathrm{NO}_{3}=1.7 \%$.

\section{F. Pate of Addition and Tine of Aging}

thate of preolpitant addition and aging of procipitate have alwars beon inportant factore in the successful developnont of an process.

Present information saows no evidence that the rate of thorium nitrate addition has any influonce on the resultis of the process. Numerous runs wore undertaken in which the procipltant was addod rapidiy to the solut1on. Eeficiont agitation with addition of the thorium nitrate solution seoms to insure quantitativenose of the reaction almost imediatoly, and as presupposed, it 10 no longer neveseary to extend the time of aginger the 
procipitate, more than 15 minutos, aftor addition of tho precipltant.

In the runo lilustratod in Táble IV a olose study vas medo of rato addition of the procipltant, timo of aging and correoponding offiwont anelyale. In practically all cases, it appoared that uranium solubilitis wes at a minimin about 25 nimutos aftor complotion of the reaction. This Immodiate quantitativeness is of primo importance in reducing the tino oloment of the crolo.

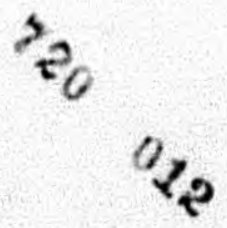




\section{TABIE IV}

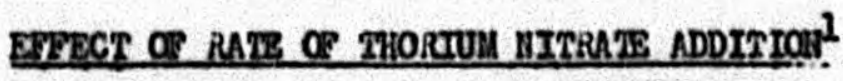

\section{AND MIES OS AGIP OS PENCIPITATE}

\begin{tabular}{|c|c|c|c|}
\hline n & 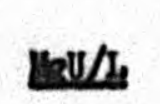 & $\begin{array}{l}\text { Timo of Aging Bofore } \\
\text { Canteriogation in wine. }\end{array}$ & $\begin{array}{l}18 \mathrm{~B} \text { O/L of Centrifuged } \\
\text { Efenent }\end{array}$ \\
\hline 44 & 28.1 & 5 & .033 .03 \\
\hline 37 & 28.1 & 5 & $.723 \cdot 66$ \\
\hline 38 & 28.3 & 3 & $.32 ; \cdot 29$ \\
\hline 49 & 28.1 & 20 & $.28\} .11$ \\
\hline 45 & 28.1 & 15 & $.05 ; .05$ \\
\hline 47 & 28.1 & 15 & $.09 ; .09$ \\
\hline 48 & 28.1 & 25 & $.22\} \cdot 16$ \\
\hline 50 & 28.1 & 15. & .073 .07 \\
\hline 51 & 28.1 & 15 & $.08\} \cdot 12$ \\
\hline 43 & - 28.2 & 30 & $\cdot 203 \cdot 20$ \\
\hline 36 & 28.1 & 45 & $.22 ; \cdot 22$ \\
\hline 46 & 28.1 & 45 & $.243 \cdot .15$ \\
\hline-44 & 31 & 15 & .051 .03 \\
\hline$B-45$ & 22 & 15 & $.22\} \cdot .22$ \\
\hline$B-46$ & 24 & 20 & $.071 \cdot 07$ \\
\hline $4^{\prime}$ & 23 & 20 & $.07 ; .03$ \\
\hline
\end{tabular}

Condifiongs 2011 tor polutions procipitated $\mathrm{Th}=1 \mathrm{gr} / \mathrm{L}_{3}$ $\mathrm{pH}=2.0 \odot 4^{\circ} \mathrm{C} ; \mathrm{H} \mathrm{O}_{2}=.5 \mathrm{H}$. Synthot10 solution approxdmating actina Bota offluent used - $F_{0}=$ $.05 \%, \mathrm{Ca}=.3 \%, \mathrm{Ca}=.2 \%, \mathrm{Cr}=\mathrm{N1}=.02 \%, \mathrm{~m}_{4} \mathrm{Cl}=$

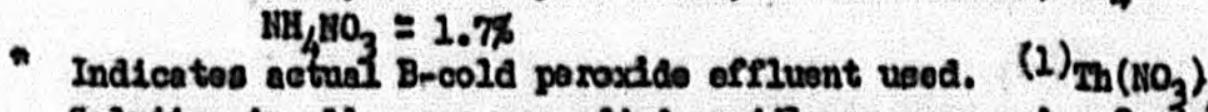
Solution in all cases was added rapidhy or over a 1 - 2 minut to perlod. 


\section{O. Eefluent Salt Concentration}

Since the plant offluentis contain eufficient oalt concentration, no furthor addition is t.900ssary.

Synthot1c runs wore usua2ly enhanoed with approxdante2y a $3 \%$ $\mathrm{NH}_{4} \mathrm{NO}_{3}$ Bolution to inururo the rapid coagulation of tho proolpitate.

Actual plant and synthetio runs were stualed closely with and Wh thout the adaition of eleotrolytes. In each case, whore synthot1c rume were proeipitated without tho addition of eloctrolytos, extonsivo delay was observed in the tiso of precipltetion and rarely was the procipitation quantitativo.

In the prosence and absence of additional eloctrolytios to ectual plant effluents, the offlolency of recovery renainod unaffectodo

TABLE V

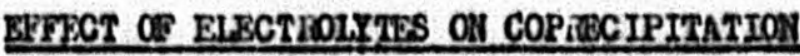

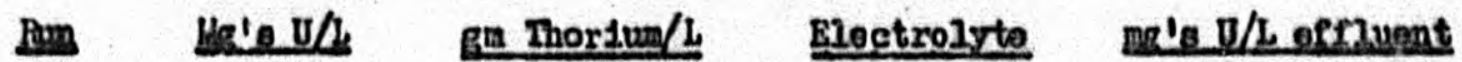

40

30.5

1

- -

$1.02, .99$

41

30.5

1

3\% $\mathrm{NH}_{4} \mathrm{Cl}$

$.12, .27$

*B-40

30.0

1

$\cdots$

:06, .06

"B-41

24

1

$3 \% \mathrm{NH}_{4} \mathrm{NO}_{3}$

$.12, .06$

\section{Conditions: $\mathrm{pH}=2.0 \bigcirc \mathrm{L}^{\circ} \mathrm{C}, \mathrm{H}_{2} \mathrm{O}_{2}=.5 \mathrm{H}$ actual and aynthotio} gunks used to maks up procipitating modium.

* Aotual cold poroxide machine vash effivent.

\section{Centrifugation}

Great care 1s necessary in adjusting the rate of centrifugation. If not controllod properily, this sinple oporation nay roadily reggut in the loss of considerable uranium.

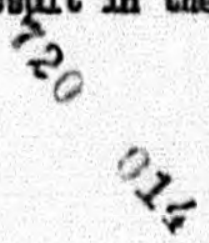


In the laboratory pllot plant, one 11tor por 2-1/2 nimutes seomed a reasonable rate for suocosoful centrifugation. Frequant eanpling of the offivent may shon alow formation of solld material. Thts, obvlously ind1cates too rapid contrifugation and accordingly, the flow rato should Irmodiatoly bo. reduoed uatil the ooparation lo couploto.

P1lot plant rune at Purdue Univeralty involving 100 gellon egnthet1o batches, wuccosafully averaged approxdmately one gallon per vinuto for centrifugation. It 1s obvious then, that off 1cioncy of the procese inoreases also vIth alse and type of equipment.

\section{Gantitative Data Envoloping the Copreolnitation of Uraniur and Theriun Pexexides Exon Sinthatte Solnt1ons}

\section{A. Pllot Plant Data}

A sorles of runs, Table VI, utlilsing 15 Liter synthot10 solvtlons previously enhanced $\pi$ th sufficlont lon concentrations comperable to those found in Beta cold peroxide machine wash offluents, wero conducted in the laboratory on a pllot plant soale.

Bach run was made undor predeternindd basic optimum conditions; $\mathrm{pH}=2.0, \mathrm{H}_{2} \mathrm{O}_{2}=.5 \mathrm{H}$, temp, $=4^{\circ} \mathrm{C}, 2 \mathrm{gr}$ Thorluma/h. For control purposes the concontration of Vranlum was maintained constant, excopt in a for cases where the offect of 1 te concentration was being investigated.

Considerable omphasis was lald on rato of addition of the procipltant and tino of aging bofore contrifugation. Although 15 minutes seem sufflolent for addition and aging tine before centrifugation, it is well to note that this time is not a oritical factor, for the precipitation is practically quantitative immodiately.

In all runs excopt whore extreme varlations were exerted, effluent

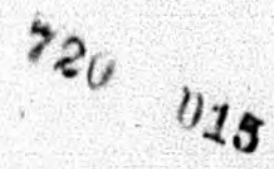


analygis wero nell under $2 \mathrm{mg} / \mathrm{gra} 2 \mathrm{Las}$.

The pH $2.38 \bigcirc 4^{\circ} \mathrm{C}$ was taksn as corresponding to $\mathrm{A} 10 \mathrm{~A}$ ebneontratlos

of $1.0 \times 10^{-2}$ from Beclaman temp. corrections, after tho Beckman motor was adjustod to read 4.0 whon the elootrodes wero Immersed in standard pll 4.0 buffer at $25^{\circ} \mathrm{C}$. 


\section{$>$}

TABLE VI

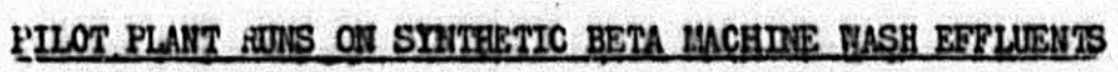

\begin{tabular}{|c|c|c|c|c|c|c|c|c|}
\hline Pan & $\begin{array}{l}\text { Volume of } \\
\text { Solution }\end{array}$ & $\mathrm{pA}^{*}$ & 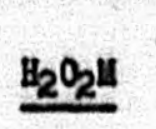 & $\begin{array}{l}\text { In1tiel Thorlum } \\
\mathrm{mg} / \mathrm{L}\end{array}$ & $\begin{array}{l}\text { In1tial U } \\
\mathrm{me} / \mathrm{h}\end{array}$ & $\begin{array}{l}\text { Ite } \mathrm{O} / \mathrm{L} \\
\text { Efefluent }\end{array}$ & \multicolumn{2}{|c|}{$\begin{array}{l}\text { Total Tine for Rate of Adaltion } \\
\text { and Aeing Bofore Centrif rugation }\end{array}$} \\
\hline 36 & 20 & 2.38 & .5 & 1000 & 28.6 & $0.22,0.22$ & $45 \mathrm{~m}$ & inutes \\
\hline 37 & 20 & 2.38 & .5 & 1000 & 28.6 & $.72, \quad .66$ & 5 & " \\
\hline 38 & 20 & 2.38 & .5 & 1000 & 28.6 & $.32, .29$ & 10 & $n$ \\
\hline 39 & 20 & 2.38 & .5 & 1000 & 108 & $3.6,3.6$ & 1 ho & oux \\
\hline 40 & 15 & 2.38 & .5 & 1000 & 30.5 & $1.02, .99$ & no olectroly & to edded \\
\hline 41 & 25 & 2.38 & .5 & 1000 & 30.5 & $.12, \quad .27$ & $\mathrm{NH}_{4} \mathrm{Cl}$ added & \\
\hline 12 & 20 & 2.38 & .5 & 1000 & 108 & $.93, .67$ & $1 / 40$ os $00_{4}$ & \\
\hline 43 & 15 & 2.38 & .5 & 1000 & 28.1 & $.20, \quad .20$ & $30 \mathrm{~m}$ & Inutos \\
\hline 44 & 15 & 2.38 & .5 & 1000 & 28.1 & $.03, .03$ & 10 & " \\
\hline 45 & 15 & 2.38 & .5 & 1000 & 28.1 & $.05, .05$ & 15 & " \\
\hline 46 & 15 & 2.38 & .5 & 1000 & 28.1 & $.24, .15$ & 45 & " \\
\hline 47 & 25 & 2.38 & .5 & 1000 & 28.1 & $.09, .09$ & 15 & $n$ \\
\hline 48 & 15 & 2.38 & .5 & 1000 & 28.1 & $.22, .16$ & 15 & $"$ \\
\hline 49 & 15 & 2.38 & .5 & 1000 & 28.1 & $.11, .11$ & 10 & $n$ \\
\hline 50 & 15 & 2.38 & .5 & 1000 & 28.1 & $.07, .07$ & 15 & " \\
\hline 51 & 20 & 2.38 & .5 & 1000 & 28.1 & $.08, \quad .12$ & 15 & " \\
\hline
\end{tabular}

Temperature $4^{\circ} \mathrm{C}$. Composition of syathetic equnk $\mathrm{FO}_{0}=.05 \%, \mathrm{Ca}=.3 \%, \mathrm{Ca}=.1 \%, \mathrm{Cr}=\mathrm{N1}=.02 \%$, $\mathrm{NH}_{4} \mathrm{Cl}=\mathrm{NH}_{4} \mathrm{HO}_{3}=1.75$.

In overy caso ligs. Orantum /L offunant were analyzed in lar. C. D. Susano's Laboratorlos by Pentaiv Thorium added as $10 \% \mathrm{~m}\left(\mathrm{NO}_{3}\right)$, solution.

* See page 15, last paragraph for pll convention. 


\section{B. Vee of Phorcled Thuriun in Urantum-Thortun Peroxdide}

\section{Conaresustation}

Since the wt, thorium / wt, urensium ratio 20 - 30 has proven most Batiafactory, it was docided to reclatem and rouse the original charge of thorlin as many timse as necessary to prove the feaslbility of treating the aotual plant materlal in such a nanner.

A 15 I1tor oynthot1c solution ontulating a typical mechino wash offluent was precipltated under optimun conditions. The $\mathrm{Th}_{2} \mathrm{O}_{7}-\mathrm{UO}_{4}$ cake was treatod with oxplic aold, the resulting Insolublo Thorlum oxalato decomposed

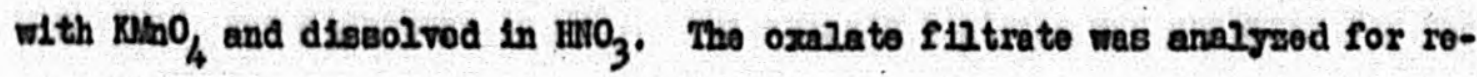
covered T.

The eolution containing the roclained thorium was roturned to anothor original agnthetic machino wash offluent for reuse as the precipltant.

This procedure was repoatod as many times as indicatod under "Roogole $\not "$, Tablo VII.

TABIE VII

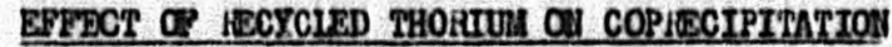

\begin{tabular}{|c|c|c|c|c|c|}
\hline Barcie & $\begin{array}{l}\text { In1tina Th } \\
\operatorname{mrg} / 1\end{array}$ & $\begin{array}{l}\text { Insts } \\
\text { and } \\
\text { iotail }\end{array}$ & $\frac{1}{8}$ 茂 & $\begin{array}{l}\text { Hge } 0 / L \\
\text { effervent }\end{array}$ & $\begin{array}{l}0 \text { in Ox elitrato } \\
\text { MRB. }\end{array}$ \\
\hline 0 & 1000 & 458 & 30.5 & $.15, .12$ & 421 \\
\hline 1 & 1000 & 458 & 30.5 & $.28, .24$ & 482 \\
\hline 2 & 1000 & 458 & 30.5 & $.30, .21$ & 461 \\
\hline 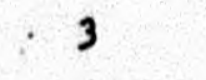 & 2000 & 458 & 30.5 & $.31, .31$ & $448^{\circ}$ \\
\hline 4 & 1000 & 458 & 30.5 & $.60, .48$ & 416 \\
\hline 5 & 1000 & no 0 & added & $.06, .06$ & 29.7 \\
\hline 6 & 1000 & 458 & 30.5 & $.60, .53$ & 451720 \\
\hline 7 & 1000 & 458 & 30.5 & $.21, .15$ & 434 \\
\hline
\end{tabular}


A Uranium balance on the recyele Indicatod that of the total 3206 mgo. Involved, 3135 mge wrore accounted for in the oxalato filtrato and 35 ag oscaped ndth the Thorlum offluont. Rosulto basod on volumotric and Pluosesconoo analyols roopoctively.

Rotuse of 15 grams of Thorim as a procipitent on olght woocoselvo sumb, these resulted in a $98 \%$ recovery of Vranlum and an average offinent $108 B$ of woll under $1 \mathrm{mg} / \mathrm{gallon}$. The unacoounted $2 \%$ can be attributed to the prepent inafficlont lasoratory pllot plent contrifugation aystom.

It is safe to asetune that with the Increasod off 101ency of contrifugation and general procedures resulting from actual large scalo plent equipmost, no matorial w13.1 remain unacoounted for. Sone data is presentity iavallarlo on the $108 \mathrm{~s}$ of thoriun from the original charge (see page). According to Alpha counting oxporiments", and $\mathrm{Th}_{8} \mathrm{O}_{7}$ solubllity dote.minations" oquilibrium conetante for Th and $U$ showi-

$$
\begin{aligned}
& \frac{(\mathrm{Th})\left(\mathrm{H}_{2} \mathrm{O}_{2}\right)^{3 / 2}}{(\mathrm{H})^{4}}=\mathrm{x}=1.5 \times 20^{-3} \\
& \frac{\left(\mathrm{UQ}_{2}\right)\left(\mathrm{H}_{2} \mathrm{O}_{2}\right)}{(\mathrm{H})^{2}}: \mathrm{x}=1.3 \times 10^{-3}
\end{aligned}
$$

Slace thorium solublisty is relativoly oinllar to that of uranium, then on a plant scalo, ono pound of thorlum can be ouccesafully reused wang timos without Pear of Elgalficantig realucing the eptimum $\mathrm{Th} / \mathrm{nt}$. 0 rat1o.

$\checkmark$ quantitative Data Eaveloping Copreolpitation of $\mathrm{Th}_{2} \mathrm{O}_{7}-\mathrm{UO}_{4}$ from 1300 Gyole Hachine Rash Befiuents.

\section{A. Pllot Dinnt Data}

* Fork done by H. Cragg and H. Grady respectively. A more corploto disoussion of theee phases olill bo presented in separate reports in the near future. 
A Berlos of 52 runs wore carrlod out on actual machine wash eff 2uonte obtained from the Bota plant after cold paroxdide treatment of machino wash Eolutione.

Two batches each day were recolved from the process group. These batches, usual1y 18-20 11ters, ตอre malntelned at $4^{\circ} \mathrm{C}$ unt1l preo1pitation.

Prior to precipltation, samples of each corresponding batoh rocolvod wore analyzed by C. D. Susano's group for total uranium. As tho 1nitial uranium concentration varied considerably day by day, it mes cocidod to obtain a rapid polarographio analysis. Thls mothod noticeably decreaser In offlolenoy with increasing uranium concentration and so, too wuch omphaals cannot be placed on the results, if a uranium balance is being sought. The analysis was doolred primarily for a rough doternination of the total uranium presont and thus on ontiaste of the offlolonoy of the thoriun carrlor mothod.

Effluenta from the thoriun copreolpitation were analyzed by the more accurate and rollable fluoresoenoe method.

Opon recolpt of the effluent, a pormanganimotric determination for $\mathrm{B}_{2} \mathrm{O}_{2}$ was performed. The $\mathrm{pH}$, if necessary, was adgusted to 2.38 at $4^{\circ} \mathrm{C}$ before addition of ourficiont $\mathrm{H}_{2} \mathrm{O}_{2}$ to make the offluent .5L.

A $10 \%$ aqueous solution of the $\mathrm{Th}\left(\mathrm{HO}_{3}\right)_{4}$, based on one gram of Thorlum/11ter of offuent, mB added to the solution and the pll readjustodIn cases whore necessary. Quite of ten the pll of the plant machine wash offluent recleved in the laboratory ranged froa $2.6-2.8 \div 4^{\circ} \mathrm{C}$, and in this case no adjustment was necossary, for upon addition of the thoriun, the pll uevaly dropped to $2.3 \oplus 4^{\circ} \mathrm{C}$ or the true $\mathrm{pH}=2.0 \times 25^{\circ} \mathrm{C}$.

Contrifugation mas uewally in progress 15 minutes after procip1- 
20.

tation and two offluent samples in each case vere takon for analyels.

Table vIII.

The purpose of using actual plant effluents was toufold. Firet to measure realistloally tho officlones by which small quantition of uraniun could be recovered with ald of the thordun coproclpltation process, and second, the soparation of uranitim from thorium and reclamation of thorlus for reuso as a procipitant.

Is can bo establishod from Table VIII undor column labolod "Gycle ft", the indtial charge of 20 grams of thordum - based on tho avorage volumo and 1 gram Th/11ter - was recovered and reused a total of eeven timos.

The method of reoyclo conslated of combining olx separate charges of thorlum as $\mathrm{Th}\left(\mathrm{C}_{2} \mathrm{O}_{4}\right)_{2}$ into one largo batch, from which the total thordum was recovered as $\mathrm{m}\left(\mathrm{HO}_{3}\right)_{4}$. The recovexed thorlum was divided into 6 oqual volumes and reused as previously. This process was ropeated on 7 occasions.

After the fifth rocyclo, it was found that $90 \%$ of the initial thorium charge was still presont. Tho final two recyclos showod no decrease In the thorium carrier officioncy.

Tho thorium loss was of no great consequence for $1 t^{\prime}$ s 1 itinl rat10 of 20-30, wt. $\mathrm{Th} / \mathrm{wt}$. $\mathrm{J}$, was conoluerably in excess. Nevertheless $1 t$ may be valuable practice to chock the strength of thorium in the recyclo at verlous intervais at the start of the processe. Since $\mathrm{Th}_{(\mathrm{C}}\left(\mathrm{C}_{2} \mathrm{O}_{4}\right)_{2}$ is verg insoluble, theoreticalis the oniy thorlum capablo of escaping is that through poor contrifugat1on.

As prevlously stated, the polareraphlo analyolo offero no great accuracy with increesing uranium concontratione, results, often varying by 10\%. Thus no desire to maintain on accurato uraniua balence was intendod.

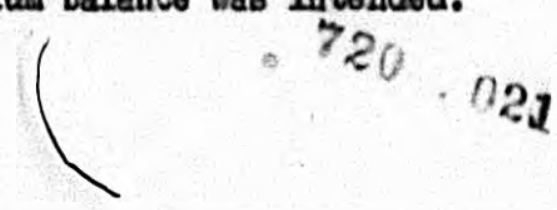


TABIE VIII

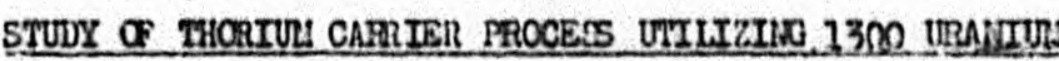

\begin{tabular}{|c|c|c|c|c|c|c|c|c|c|c|c|c|c|}
\hline Run & $\begin{array}{l}\text { Effivent } \\
\text { Volume } \\
\text { in Isters }\end{array}$ & $\begin{array}{l}\text { Inftial } \\
\text { Urant um } \\
\text { Lge }\end{array}$ & Start & Finish & "1/202" & $\begin{array}{l}\text { Cycle } \\
\text { fi }\end{array}$ & $\begin{array}{l}\text { Aglng } \\
\text { hrs. }\end{array}$ & $\begin{array}{l}\text { Centrifuged } \\
\text { hrs. }\end{array}$ & $\begin{array}{l}\text { Uranium } \\
\text { Effluent-mgs }\end{array}$ & & Rerm $r$ & & \\
\hline B- 7 & 20 & 76 & 2.7 & 2.4 & .5 & 0 & $1 / 2$ & 1 & $.03, .14$ & $350 \mathrm{graNh}_{4} \mathrm{HO}_{3}$; & $350 \mathrm{NH}_{4} \mathrm{Cl}$, & , $400 \mathrm{ccl}_{2} \mathrm{O}_{2}$ added & \\
\hline B- 6 & 20 & 72 & 2.6 & 2.38 & .5 & 0 & $n$ & $\pi$ & $.16, .16$ & $"$ & $n$ & $n$ & \\
\hline$B-8$ & 20 & 100 & - & 2.38 & .5 & 0 & $"$ & $n$ & $.03, .03$ & $n$ & $n$ & $n$ & \\
\hline B -9 & 20 & $\%$ & - & $n$ & .5 & 0 & $"$ & $n$ & $.03, .03$ & $"$ & $"$ & $n$ & \\
\hline B-10 & 15 & 81 & 2.6 & $"$ & .5 & 0 & $"$ & $"$ & $. \alpha_{4}, .07$ & 250 & 250 & 300 & \\
\hline B-11 & ab & 84 & 2.6 & $n$ & .5 & 1 & $"$ & $"$ & $.44, .66$ & 350 & 350 & 350 & \\
\hline B-12 & 20 & 44 & 2.8 & $"$ & .5 & 0 & $"$ & $"$ & $.03, .03$ & " & " & $n$ & \\
\hline$B-13$ & 20 & 44 & 2.8 & $"$ & .5 & 0 & $n$ & $"$ & $.03, .03$ & $n$ & $"$ & $n$ & \\
\hline$B-W_{4}$ & 20 & 15 & 2.8 & $n$ & .5 & 2 & $"$ & $n$ & $.0), .23$ & n & $"$ & $n$ & +3 \\
\hline B-15 & 20 & 12 & 2.8 & $"$ & .5 & 0 & $"$ & $n$ & $.07, .13$ & $"$ & $n$ & $n$ & \\
\hline$B-16$ & 20 & थ2 & 2.75 & $\because$ & .5 & 1 & $"$ & $"$ & $.22, .29$ & $"$ & $a$ & " & \\
\hline B-17 & 20 & $a_{4}$ & 2.75 & $"$ & .5 & 2 & $n$ & $"$ & $.22, .22$ & $n$ & $"$ & $n$ & \\
\hline$B-18$ & ab & 120 & 2.3 & $"$ & .04 & 2 & $"$ & $n$ & $.06, .09$ & $n$ & - & $\mathrm{H}_{2} \mathrm{O}_{2}$ titrato $\mathrm{his}_{3} \mathrm{gith}_{4}$ & \\
\hline $3-19$ & 20 & - & 2.3 & $n$ & 245 & 2 & a & $n$ & $.06, .09$ & $"$ & - & $n \quad 5$ & \\
\hline$B-20$ & 20 & 48 & 2.8 & $n$ & .45 & 2 & $n$ & $"$ & $.03, .03$ & $"$ & - & 720 & 1132 \\
\hline n-21 & 20 & 63 & 2.8 & $"$ & .143 & 2 & " & $"$ & $.06, .06$ & $n$ & - & " n n & \\
\hline B-22 & 19 & - & - & $"$ & $.3 / 4$ & 3 & $n$ & $n$ & $.09, .15$ & $"$ & - & $.16 \underline{H} \mathrm{H}_{2} \mathrm{O} 2$ added & \\
\hline D-23 & 20 & - & - & $\stackrel{n}{*}$ & .33 & $\begin{array}{l}3 \\
\text { (Cont }\end{array}$ & $n$ & n & $.12, .15$ & $"$ & - & $.17 \underline{\underline{z}}$ & P \\
\hline
\end{tabular}




\section{TABLE VIII}

(Continied rrom the preceding page)

STUDY OF THORTUL CARRTER PROCESS UTHLIZTNO 1300 URANTUS

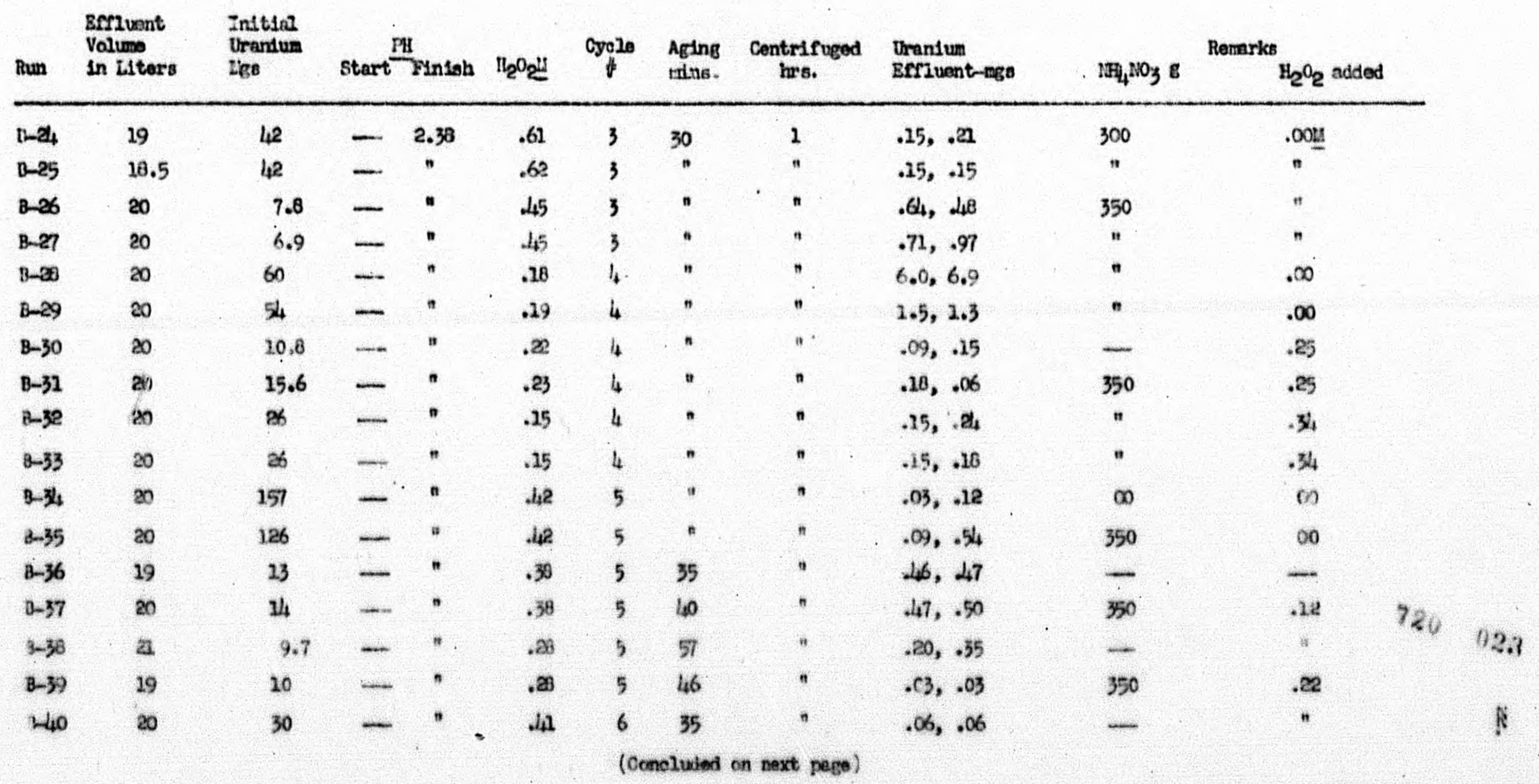


TABIS VIII

(Continued from preceding pago)

STUDY OF THORTUR CARRTER PROCESS OMTHZTINO 2300 URANTUS

\begin{tabular}{|c|c|c|c|c|c|c|c|c|c|c|c|c|}
\hline Run & $\begin{array}{l}\text { Effluent } \\
\text { Voluna } \\
\text { in Istere }\end{array}$ & $\begin{array}{l}\text { Initial } \\
\text { Urantuat } \\
\text { Iles }\end{array}$ & Start & Finiah & $\mathrm{HeO}_{2}$ & Gyclo & $\begin{array}{l}\text { Acing } \\
\text { uline. }\end{array}$ & $\begin{array}{l}\text { Centriffuged } \\
\text { hris. }\end{array}$ & $\begin{array}{l}\text { Uranina } \\
\text { Bfnuent-ngs }\end{array}$ & 17: $110_{3} \mathrm{~B}$ & Ramarka & $\mathrm{H}_{2} \mathrm{O}_{2}$ added \\
\hline$B-42$ & 20 & 연 & - & 2.38 & .41 & 6 & 40 & 1. & $.12, .06$ & 350 & & .104ي \\
\hline$B-42$ & 20 & 25 & - & " & .38 & 6 & 105 & $1-1 / 2$ & $.16, .19$ & - & & .11 \\
\hline$D-43$ & 20 & 26 & - & $n$ & .38 & 6 & 25 & $"$ & $.61, .10$ & 350 & & .12 \\
\hline$B-4 L_{2}$ & 20 & 31 & - & $n$ & .37 & 6 & 15 & $"$ & $.12, .05$ & - & & $"$ \\
\hline$B-45$ & 20 & 22 & - & $n$ & .37 & 6 & 15 & $n$ & $.05, .03$ & ऊо & & .13 \\
\hline $3-46$ & 19 & al4 & - & " & .26 & 7 & 20 & $"$ & $.07, .07$ & - & & " \\
\hline$B-47$ & 19 & 23 & - & $n$ & .26 & 7 & 20 & $n$ & $.07, .03$ & 350 & &.$a_{4}$ \\
\hline$B-48$ & 18 & 32 & - & $n$ & .62 & 7 & 15 & " & $.22,: 07$ & - & & $n$ \\
\hline$=4$ & 18 & ln & $\cdots$ & $n$ & .62 & 7 & 25 & $"$ & $.00, .00$ & $\ldots$ & & - \\
\hline$B-5 C$ & 19 & 25 & - & $n$ & .25 & 7 & 15 & $n$ & $.95, .02$ & - & & .25 \\
\hline$B-51$ & 18 & 47 & - & " & .25 & $i$ & 25 & " & $.26, .32$ & 350 & & $n$ \\
\hline
\end{tabular}

Contitions: Thorium $=2 \mathrm{gx} / \mathrm{L}_{3} \mathrm{H}_{2} \mathrm{O}_{2}=.5 \mathrm{E} \quad \mathrm{PH}=2.0$ at $25^{\circ} \mathrm{C}$ or $2.3804^{\circ} \mathrm{C}$ efriuent from actuni cald $\mathrm{H}_{\mathrm{C}} \mathrm{O}_{2}$ prucipitation used na procipitatine modium. 
Tho prite purposo was to prove the offlolenoy of the earrior procedo on actual plant materlel and of 225 gallons treated the offluont loss averaged woll bolon $1 \mathrm{mg} / \mathrm{gal}$.

\section{B. Eefent of Tomparature on Consecipitation}

Bocont2y a dosire was exprossed to Investigato the posalbility of carrying tho reaction out at highor tomporatures.

It does not ceen very foasible to carry the reaction ctic at roor temporature $25^{\circ} \mathrm{C}$, in the prosonoe of $\mathrm{B}_{2} \mathrm{O}_{2}$ decompooing 10ns. Al though theis concentrations are not great, the reoulting odtalytio aotion on the docoso position at $25^{\circ} \mathrm{C}$ eay bo wuffiolent to retard, and caubo incomploto preolpltation along w1th considorablo contanination of the proolpltate.

Since it is not reasonable to expoct that the teriperature of a cold poroxido machino wash offluent, upon prolonged standing and contimud vater cooling, whould rlee above $15^{\circ} \mathrm{C}$, this temporature was selocted as tho beals for further investigations.

TABIS IX

ACTIOA of COPECGPITATIOU AT $15^{\circ} \mathrm{C}$

\begin{tabular}{|c|c|c|}
\hline 1 Ltar solutiong preolpitatod & An 1 & Pan 2 \\
\hline Settiling of preclpitate & noraal & normal \\
\hline $\mathrm{H}_{2} \mathrm{O}_{2}$ decounpose & $n$ & " \\
\hline Lge v/L orpuent. & .22 & .24 \\
\hline
\end{tabular}

Condit1ong: $\mathrm{Th}=1 \mathrm{gs} / \mathrm{h} . \mathrm{V}=22.9 \mathrm{ng} / \mathrm{L}, \mathrm{Bk} \mathrm{O}_{2}=.5 \mathrm{H}, \mathrm{pda}=2.0$, Tomp. $=15^{\circ} \mathrm{C}$.

Actual thorium contrifuge efrlueat from orlginel Bota machino wosh effivent ubed for procipitating mediua. Both solutions flltored 10-15 elnutes after 
25.

procipitation.

Both preclpitates settled at a norwal rate and $\mathrm{H}_{2} \mathrm{O}_{2}$ decomposition, although normal, was notiooably more rapld than runs at $4^{\circ} \mathrm{C}$.

Eefluent analysis Indicato that both runs are bolow 1 ag $0 /$ gallon.

Further Investigation on the action of higher tomperatures is contomplated shortig on munerous pilot plant batohos.

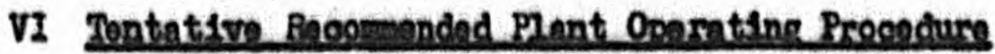

It is Intondod by the proposed operating procecturo to develop a basio plan for plaat ueo whloh will Include spocific optsman conditions

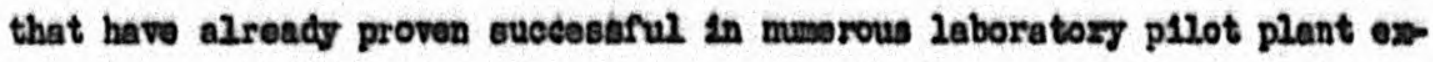
perimante.

As stated this is norely a baeis plen, and undoubtodiy considerablo oirticiea and Improvements cen bo offered.

1. Adjuat the pll of the peroxdde offluent from the machino wash to $2.7-2.8 \times 10^{\circ} \mathrm{C}$ "approxdmato $2 \mathrm{y} 2.35$ at $25^{\circ} \mathrm{C}$ with the appropriato noutralleing egent.

2. Titrato peranganimotricaliy, en ellquot eamplo of tha offluent for avallablo $\mathrm{H}_{2} \mathrm{O}_{2}$ and add oufficient $303 \cdot \mathrm{H}_{2} \mathrm{O}_{2}$ to make tho solution .5y.

3. Add to the offluont, over a fen nlauto perlod, a $10 \%$ aqueous Thoriun nitrato oolutioa $1 \mathrm{E}$-Thoriua/11tor efmuent .

4. Upon comploto edastion of the thoriun solution, the pH $14^{\circ} \mathrm{C}$ should drop to $2.3-2.4$. If belon or above this range, readjust vith appropriato acld or baso.

5. Agltate colution for 5 elinutes after precipltation, and begin

- Soe page 15, last paragraph, for pll convention 
centrifugation about 29 minutos aftor reaction is complote. 810v agitation 10 neoessary throughout the centrifugation to prevent the procipitato from clogging or eeepling through the contrifuge borid in one mase.

6. Considerablo care should bo talcon to obserwo the pasage of eng solid material through tho oontrifuge. If this condition is evident, Imodiate reduetion in tho flow rate is necessary for a nore coraploto centrifugation.

7. Upon complotion of the centrefrugation the $\mathrm{Th}_{2} \mathrm{O}_{7}-\mathrm{UO}_{4}$ alke 10 quant1tativoly romoved from tho centrifuge bovil and algeotod for one hour on a stoan bath with the theoretieal, pivs $10 \%$ excess, ormale acid addod in col1d forz.

8. The Insoluble Thorlua oxalate is filtered fron the solution, treated potontiomotrically with an acid $\mathrm{KH}_{2} \mathrm{O}_{4}$ solution to docompose the oxalate and the eolution reused por escond as the pros. clpitant in the noxt cold peroxide offluont.

9. The f11trato conteining the bulk of urenium, from the machine vash efflvont, as $\mathrm{VO}_{2} \mathrm{C}_{2} \mathrm{O}_{4}$, is returned as is to an original machine wach solution for blending and procipitation by the cold peroxide treatrent.

\section{Analrtical inthoda}

\section{A. Fluorescent Aneligeis for Minute Amounts of Urantun Fith}

\section{Thoriun Prosent}

To date the fuorescence nothod of analysis for ninuto anounts of urantus in solutions with comparable thoriun concentrations has proven to bo the moet foes1blo ${ }^{3}$. 
Thorium in concentrations of $10-15 \mathrm{mg} / \mathrm{L}$ oxh1bits a quenching effeet on the analyals, but due to the sact that the thordum concentration In the reportod analysed solutions is comparablo to tho U concentration, the results can be considered apprordmating the truo values.

To oubstantlate this atatonont, eauples subasttdd for the regular pentathar extraction and Pluorescenco analyele wore also analyed by tho recently developed diethyldithlocarbanate-pluorescence mo thod.

Th1o mothod is an extension of the pentaether eluorescence and al though more tedious, elalms a higher degree of accuracy in the presence of thorium.

The method developed in the analytical resoarch gection of this division, takes advantage of the prelininary pentaether extraction. By pli adjustinent of the Bolution from the etherate to $6.7 \pm 0.1$, and the addition of a 2\% diothyldithlocarbemato solution, a complox, oasily oxtract: able titth $\mathrm{CHCl}_{3}$, 18 formed. Subsequent Pluoresconce analya1s oan then be carried out on the thorium-eree $\mathrm{CHCl}_{3}$ layer.

A ocmparison of the pentaether fluorescence and diothylaith1ocarbamato mothode follon in table X. As Indiceted, both methode agroe . fairly wo11 and differenens at the nost average no nore than a factor of $2-3$. 
TABLE $X$

COMPARTSON OF BENTA ETHER AND

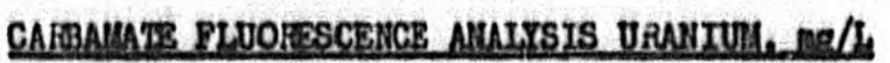

Ans

P-24

P-28

P-33

* $\mathrm{B}-4 \mathrm{4b}$

${ }^{*} \mathrm{~B}-45 \mathrm{~b}$

${ }^{*} \mathrm{~B}-45 \mathrm{c}$

\section{Panth Ether}

0.2

0.2

0.2

0.12

0.03

0.05
Corbarata

$0.18,0.17$

$0.6,0.6$

$0.29,0.45$

0.22

0.09

0.10

Above runs under opt1mun conditions.

- Indicatos 1300 material used in run.

Further ovidence supporting tho accuracy of fluorescence mothods vas obtainod from a series of runs in whloh solutions of knom uraniun concentratlons ware submitted for analysis.

In each case, resulte corresponded very closely isth the matoriel added. 
TABLE XI

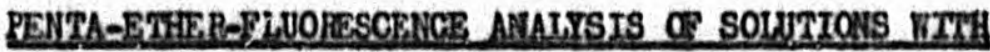

\section{KFONH URARTOH ADDED}

\section{Added Vae U Brourenoence-lige U found}

NATA-3

2.1

.96

HATB-3

.06

.15

NATE-1

.00

.12

NATE-2

.55

.52

NAID-1

.00

.00

"IIATF-2

6.3

5.7

All abovo solutions from oynthet1c thorlua effluents, preclpltated under opt1mum conditions, before urenlun added.

- Pan MATF-2 - 10ce of offluont containing $2.5 \mathrm{mg}$ uranium by previous Pluorescence analyals and sufflolent uranlum to total 6.3 ng addod.

B. Analyeis of $\mathrm{Th}_{2} \mathrm{O}_{7}-\mathrm{VO}_{4}$ Cakes sor Urantua

Is each cace where a material balance or a check on the efficlency of the thorium and uranium separation vas desired, the cako mas quantitet1vely reanoved from the contrifuge borl, digested on a stean beth for ono hour with the theoretical plus $10 \%$ excess oxalle ac1d solution and. $14 \mathrm{miO}_{3}$, and the $\mathrm{Th}\left(\mathrm{O}_{2} \mathrm{O}_{4}\right)_{2}$ f1ltiored off. The f11trate ras funed wdth $\mathrm{H}_{2} \mathrm{SO}_{4}$, Insolublo $\mathrm{SO}_{4} \mathrm{P}$ Plt tered off, and the Bolution olectrolyzed to remove $\mathrm{Pe}$ and other reduolble 10ne. Opon complotion of the electrolyels, the solution mas pased through a Jones reductor and t1trated $\nabla 1$ th $\mathrm{x}_{2} \mathrm{Cr}_{2} \mathrm{O}_{7}$ for uraniun.

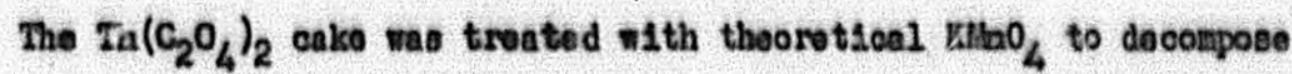
the oxalate, the Bolution treatod with $\mathrm{HClO}_{4}$, electrolyzed, and prepared for analysis as above. 


\section{Inalysis of $\mathrm{Im}_{2} \mathrm{O}_{7}-\mathrm{NO}_{4}$ Solutions for Inoreasing Thortua Conesntmition}

Oa a for occessions whore recroled thorium was ueod, it wes desired to check and eorgere it with its initial concentretion. A rapld dotarnnetion wes perforrad by precipltating en ellquot of tho Thorfun uitreto solution with $\mathrm{I}_{2} \mathrm{C}_{2} \mathrm{O}_{4}$, elltoring the $\mathrm{Th}\left(\mathrm{C}_{2} \mathrm{O}_{4}\right)_{2}$, drying and ieniting it at $1000^{*}$ to the oxtdo and celeviating per cent $\mathrm{Ft}$.

As is to bo expected for sofoty end oontrol aneaurea, a folrly repld wothod for the dotornination of ninuto anounte of thorlum in solution

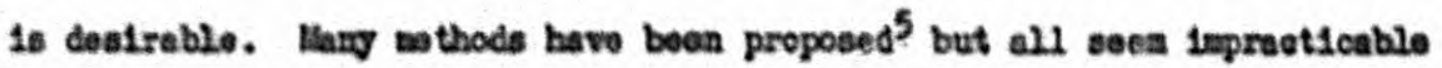
because of serious Ifintations inpoecd by the prebence of Ineressing abounts of uraniun-or fallure to dotect minute anounte of thorlun.

A search of the Litereture has produced one wathod which seems proalsing. It is oapablo of deterining thorium in tho range of 5 to 85 alerograse, w1th uronius in quant1t1es leas than 1000 mierograme causing no intorference.

The nothod zakes use of a recently reported cosplex organle re-

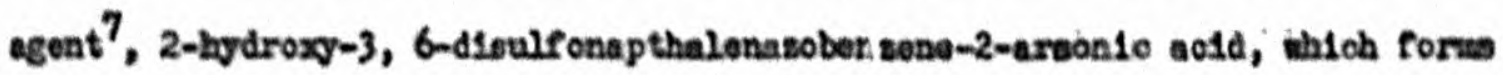
a precipltate w1th

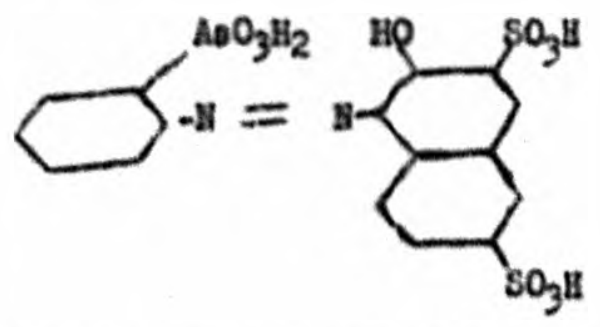

thoriun, the color of which differe from that of thu reagent. Dotormination of the thoriug present is accompliohod neroly by ph edjustront, adition of the orgen10 reagent, d1lut1on to required volumo and opectrophotoant:-1c 
nsavurenent egetengt a roference solution of the reagent.

Conaiderable work is conteaplated ahortly wth this reagent, to develop a ropld analytieel procedure or apot teat for obrious plant ceatiol purposes.

Dow to the diffleulty of obtaining tho reagent, it has recently been aynthosieed."

D. Dotorninatlon of $\mathrm{H}_{2} \mathrm{C}_{2}$ in Plant Ounks

Since it is actrantageous to malntian a $\mathrm{H}_{2} \mathrm{O}_{2}$ conecatration of $0.5 \mathrm{~g}$ oxcoss churing the resotion, It was found feesible to neseure tho $\mathrm{B}_{2} \mathrm{O}_{2}$ concentration prosent in machine wash efrivents, prior to the thorlua treatmont, by a simple pervangenisotric titration.

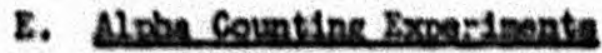

From the reeults of earlier work on the dovelopesent of a control an thod for the dotoction of alnute anounte of urenlum in the thorlua plant offluent, $\alpha$ - counting does not appear very poseiblo dun to the incomploto procipitation by $\mathrm{B}_{2} \mathrm{O}_{2}$ of ocrtain highly radio active eubetances in the thoriun salts. It wes found that tho rosidue from a singlo $t_{2} \mathrm{O}_{2}$ proolp1tation flytrate containod matorial whlch of ton gave counts up to $8000 / \mathrm{min} / \mathrm{mg}$.

It 1s obvious that a count of this wagnitude would rendor it Imposalblo to doteot evon inlligram quantitios of uraniua in tho prosence of $\mathrm{m}^{232}$ dielntogration producte $\mathrm{v}=$ approxdentoly $790 \mathrm{c} / \mathrm{m} / \mathrm{hag}$ and ang furthar attompt to dovolop an $\alpha$. counting sothod for plant control was discontinued on these grounde.

Howover, a counting mothod to cubetentieto the quatitativenoes of the thorlun oopreolpstation was developed, ut1lising proviougly purfelod

- Synthools beling carriod on by H. Crage, acoording to kuenoteov's ${ }^{7}$ mothod. 
thorlun. Fis wothod proved to be wry teclous, for it necesestated numerous ouccesativ preotpltatione of the intitel thortun.

Inereseing the aubur of precipttations and reducing the ties Intervel botwoen proeipltations produced fovorabse revults, and it wes show

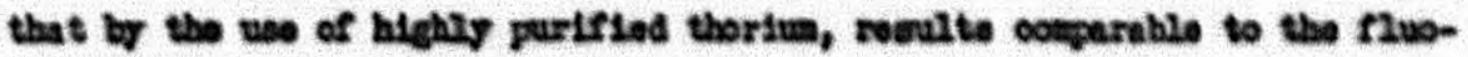
rescenes anthod could be obteitned.

An effort to reduce thls todious process of purifieation led to

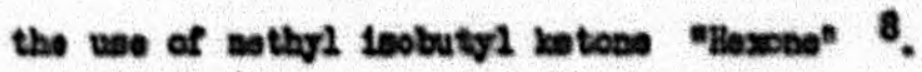

An equeous eolution of $\mathrm{m}\left(\mathrm{MO}_{3}\right)_{4}$ wee extracted with haxone, the

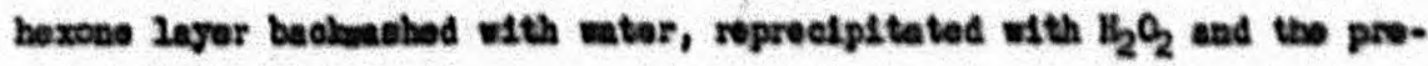
olpltate redsesolvod in $\mathrm{EmO}_{3}$.

A ainglo extraction seomd to remove proctioally all tho $\mathrm{m}^{232}$ dieintogration produots or at least redue the imparities to a count cose parablo to approxdentoly 6 succosalve $\mathrm{H}_{2} \mathrm{O}_{2}$ precipitations. The realden counts in this caen ranged from approxinately $200-150 \mathrm{e} / \mathrm{s}$ and 00 it wao

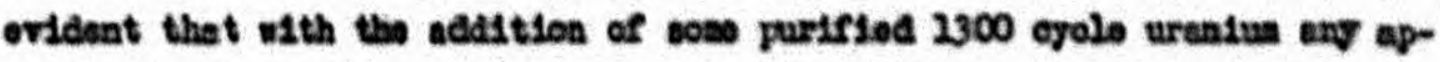
proclablo filtrats oount could then bo attributod to uraniva.

Approxdentoly one gran of 2300 urenlua was purifled by othor extreetion after oloctrolyele and counte wre taken on inereening concentrotlons of thla natorial. 


\section{-}

O- esente/tin

2100

2083

3768

5328

628

674

8224

82\%

$\% 32$

10,120
D. of e(taxe)

$.05=$

.10 .

$.20 \bullet$

$.30 *$

$.40 *$

$.50 *$

$.60 *$

.70

.90

1.0

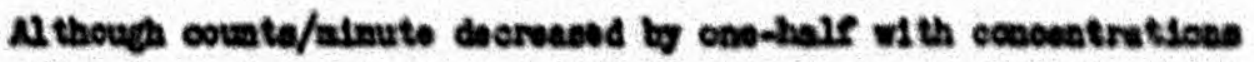

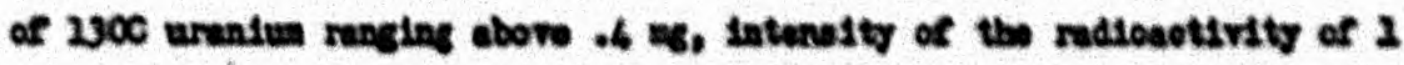

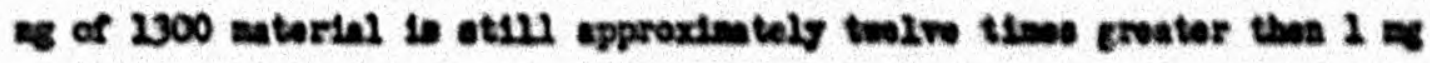

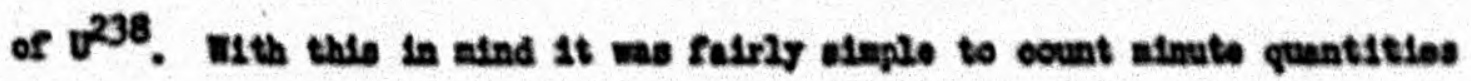
of urealua in the provence of devehter free mortua.

C.P. $\mathrm{m}\left(\mathrm{HO}_{3}\right)_{4}$ wae extreoted with bexone and balf of an all quot

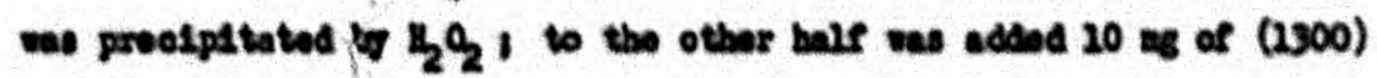

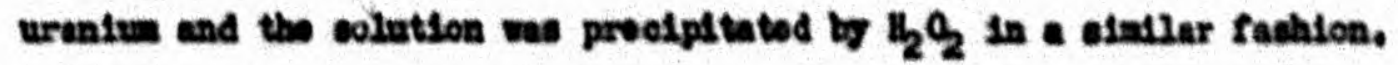
Both eolutsone wer filtared and equel portlone of the futivites oveporeted to drgneses and counted.

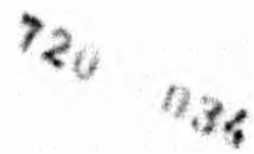


vase $\mathrm{xa}$

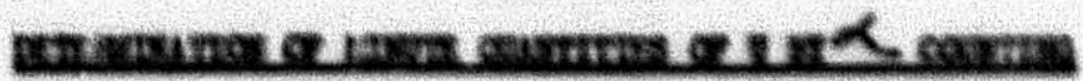

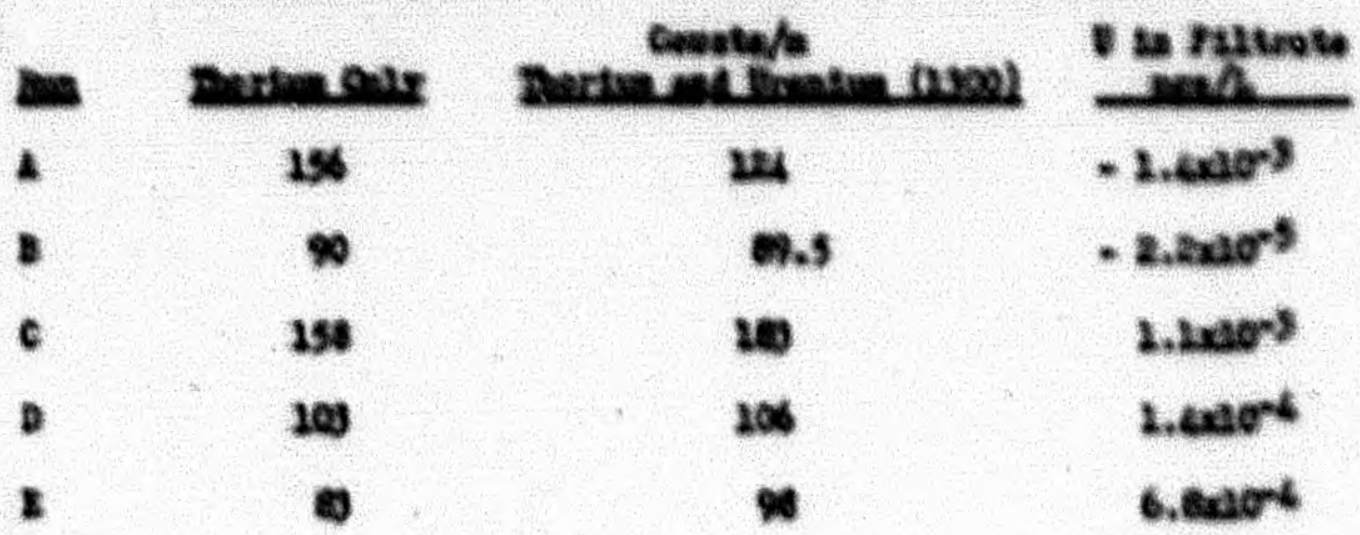

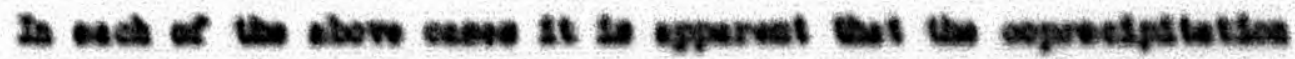

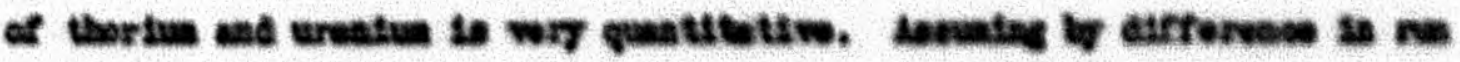

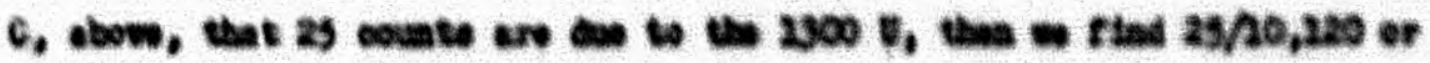

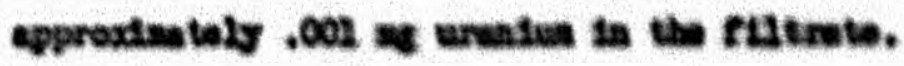


35.

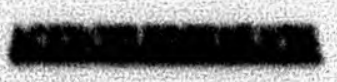

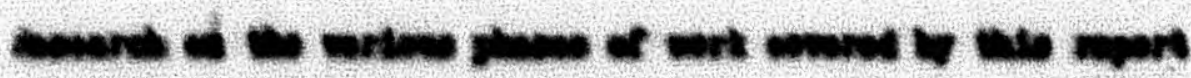

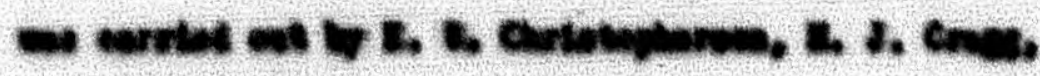

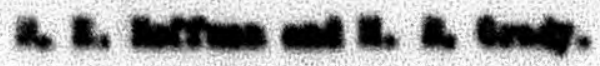

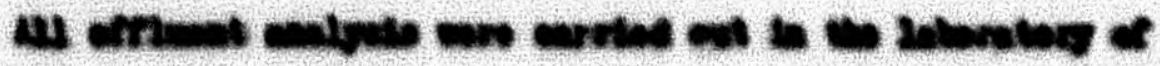

C. C. D, 


\section{Ans.}

(a). c-0.300.4.

(a). Nan.

0). Cos.36.9.

(W). C-4.10025, 26 en 27.

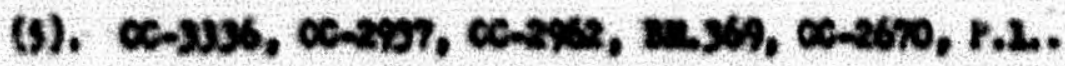

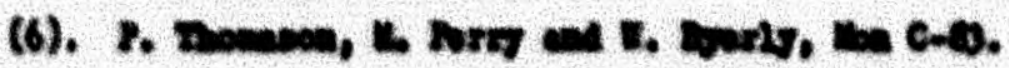

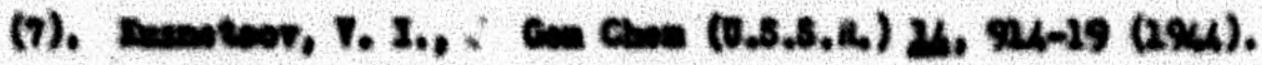

(1). cosens.

(9). C-2.3a.9.

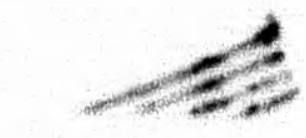


$20 / 6 b$

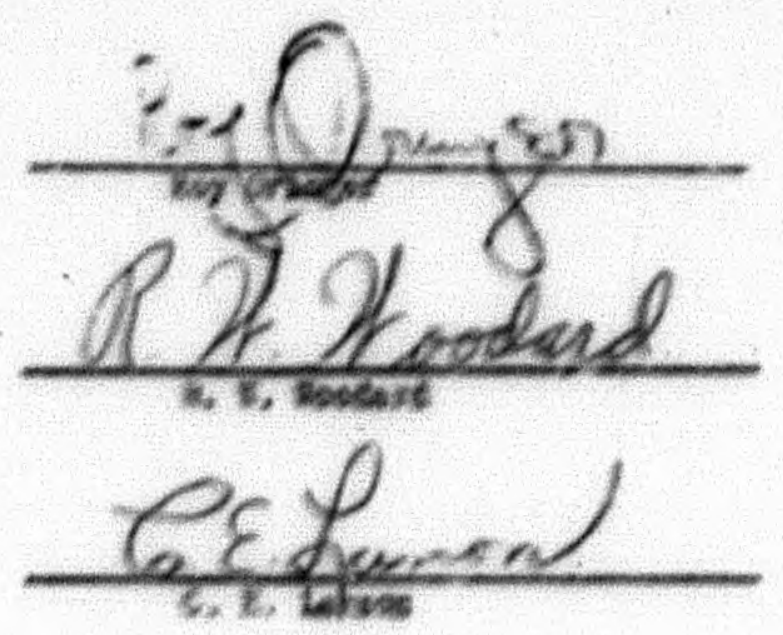

?

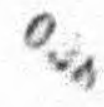

